Univerzitet u Beogradu
Poljoprivredni fakultet
Institut za poljoprivrednu tehniku
Naučni časopis
POLJOPRIVREDNA TEHNIKA
Godina XLIV
Broj 4, 2019.
Strane: $50-59$

\title{
NUTRIENT RELEASE PATTERNS FROM COMPOST, VERMICOMPOSTING, AND LONG-TERM EFFECT ON SOIL FERTILITY STATUS
}

\author{
Amos D. Umaru ${ }^{1}$, Precious O. Ehiomogue ${ }^{* 2}$, Stephen O. Ojedele Francis N. Orji ${ }^{2}$, \\ Ikechukwu Okosa ${ }^{2}$, Chidinma E. Ikechukwu-Edeh ${ }^{2}$ \\ ${ }^{1}$ Federal University of Agriculture, \\ Department of Agribusiness, P.M.B. 2373, Makurdi, Nigeria. \\ ${ }^{2}$ Michael Okpara University of Agriculture, \\ Umudike Department of Agricultural and Bio-resources Engineering, \\ P.M.B. 7267 Umudike, Nigeria
}

\begin{abstract}
The principal aim of this study was to examine the nutrient release pattern from two types of composts and long-term implications on soil fertility status. An incubation experiment was carried out in the laboratory to determine the nutrient release patterns from compost and vermicompost mixed with soil at different application rates of SC30, SC70, SC120 and SV30, SV70 SV120 respectively for 21 days. Initial preincubation analysis of the compost material used for the experiment showed that both the compost and vermicompost had high nutrient content. The results further revealed that the different rates of compost and vermicompost application to soil had significant influence on the slow, gradual release process, indicating the long-term effect the organic fertilizers could exert on soil fertility status
\end{abstract}

Key words: Compost, Vermicompost, Nutrient release, Soil fertility.

\section{INTRODUCTION}

The natural recycling of organic solid waste through composting is a management technique, which helps to provide balanced nutrients to crop roots and promote growth by augmenting the organic matter content of the soil. Numerous organic sources such as green compost and vermicompost have abundant nutrients that are considered better sources for sustainable crop production by increasing yields and growth of crops.

\footnotetext{
*Corresponding Author. Email: ehiomogue.precious@mouau.edu.ng
} 
Vermicompost refers to an organic fertiliser prepared as the vermicast from earthworms' feeding activity on waste materials mostly of biological origin [1].

It is regarded as one of the best sources of nutrients for plants, and helps to enhance the physicochemical characteristics of crops [2]. Studies showed that vermicomposting does not contain toxic enzymes, thus it is an ecologically friendly organic substance that produces positive effect on the biochemical processes of the soil, enhances soil quality, fertility, mineral content of its structure, aeration, textural properties and tilt thus reducing soil tendency to compaction [3]. Vermicomposting helps to build up water retention capacity of the soil due to its rich organic matter content, promoting nutrient absorption and root growth [4].

Field as well as laboratory experiments are required to evaluate the nutrient availability and efficacy of bio-fertiliser compost and vermicompost derived from oil palm wastes and residues. Such experiments are significant in view of the fact that the nutrient contents of organic fertilisers differ considerably [5].

A number of authors such as Chen, Lin and Yang [6] have focused attention on the potential application of nitrogen derived from animal dung. Granite powder has also been investigated and found to be a good source of slow-release $\mathrm{K}$ fertilizer [6]. However, further studies on the potential use of nitrogen from different sources such as compost and vermicomposting derived from palm oil waste in lieu of animal manure are required. Thus the objective of the present study was to determine the nutrient release pattern from two types of composts derived from palm oil waste and long-term implication for soil fertility status.

\section{MATERIAL AND METHODS}

\section{Experimental set up}

The research involved an incubation experiment to determine the nutrient release patterns from palm oil waste derived compost and vermicompost. The compost materials used for the experiment were obtained from Malaysian palm oil industry. The soil used was the ordinary sandy soil, which was air-dried, ground and sieved using a $2 \mathrm{~mm}$ mesh sieve. The two main organic fertilisers namely compost and vermicompost were used in combination with soil in the pot experiment that were arranged in the incubator in a completely random fashion in triplicate. The treatments consisted of compost (SC30, SC70, SC120 t/ha) and vermicompost (SV30, SV70, SV120 t/ha). The soil was thoroughly mixed with the composts and moistened with $36 \mathrm{ml}$ of deionised water. The potting media were incubated inside the dark growth chamber maintained at $32^{\circ} \mathrm{C}$ over a 3 -week period. Water baths were placed at the bottom of the incubator in order to minimize water losses from the potting media due to excessive evaporation and to control the humidity of the incubator's internal environment. The initial base-line analysis of the composts used for the incubation experiment was carried out using appropriate standard laboratory procedures. The moisture as well as organic matter contents of the compost materials was also determined after drying at $105^{\circ} \mathrm{C}$ for a 24 hour period. The $\mathrm{pH}$ was determined in $50 \mathrm{ml}$ water extracts. Total carbon, organic carbon, and nitrogen were determined using Elemental Analyser (Elementa Vario EL). 
Extractable nitrogen $\left(\mathrm{NH}_{4}{ }^{+}\right.$and $\left.\mathrm{NO}_{3}{ }^{-}\right)$was determined in $100 \mathrm{ml}$ of 2 mole/l potassium chloride solution. Available $\mathrm{P}$ was analysed in ammonium bio-carbonate solution.

\section{Chemical Analysis}

The chemical analysis involved preliminary based-line characterization of the compost and vermicompost materials used for the incubation experiment to determine the typical nutrient contents prior to incubation. The properties of the compost and vermicompost examined included total carbon, total oxides of carbon, total and available potassium, total and available phosphorus, total and extractable nitrogen, loss on ignition, water content and $\mathrm{pH}$. Samples were taken from the incubated pots once every week for a time period of 21 days. Each extract from the sampled pots was analysed to determine the concentrations of mineralized $\mathrm{N}_{\text {in }} \mathrm{NH}_{4}{ }^{+}-\mathrm{N}$ and $\mathrm{NO}_{3}{ }^{-}-\mathrm{N}$ released from the different combination of treatments, and the mineralized $\mathrm{N}$ was estimated as the sum total of $\mathrm{NH}_{4}^{+}-\mathrm{N}$ and $\mathrm{NO}_{3}^{-}-\mathrm{N}$ each time. The Burkard Scientific Segmented Flow Analyser was used to determine the $\mathrm{N}_{\text {in }} \mathrm{NH}_{4}{ }^{+}$and $\mathrm{NO}_{3}{ }^{-}$.

\section{RESULTS AND DISCUSSION}

\section{Pre-Incubation Characteristics of the Composts used}

The results of the pre-incubation analysis of the compost materials used for the pot experiment are shown in

. The results of the initial chemical analysis of the composts shown in

revealed that both the compost and vermicompost had high content of nitrate (NO3- N).

Since nitrate is generally present in very low concentrations in immature composts, the high concentrations as observed in this experiment is an indication of the stability and maturity of the compost and vermicompost used in this study. The vermicompost was acidic ( $\mathrm{pH}$ 5.2), with low organic carbon content (25.39\%), and high nitrogen content of $1.92 \%$ which was above the minimum required for mature compost of $0.6 \%$ as reported by Riffaldi et al., [7] and also falls within the normal range of 0.5-2.5\% dry weight basis. The acidic nature could be due to the presence of the proton $\left(\mathrm{H}^{+}\right)$in $\mathrm{NH}_{4}^{+}$which furnishes hydroxonium ions when dissolved in water. The level of acidity is determined by the concentrations of hydrogen ions released during mineralisation of ammonium. The chemistry of this reaction is depicted in a simple equation as follows:

$$
\mathrm{NH}^{+} \rightarrow \mathrm{NO}^{-}+\mathrm{H}^{+}
$$

Where $\left[\mathrm{H}^{+}\right]$is a proton, which confers acidic properties on the vermicompost and the $\mathrm{pH}$ is the negative logarithm of the hydrogen ion concentrations represented by the following expression:

$$
\mathrm{pH}=-\log \left[\mathrm{H}^{+}\right]
$$

And it is defined as the degree of acidity or alkalinity of an aqueous medium. 
The $\mathrm{pH}$ is a measure of active acidity in the compost material, and the majority of finished composts will exhibit a $\mathrm{pH}$ in the range of 5.0-8.5. Generally, a neutral $\mathrm{pH}$ is suitable for most applications as revealed in literature. Thus, the $\mathrm{pH}$ of the compost (7.16) and vermicompost (5.02) are within the stated values for finished composts.

Although there is no ideal organic matter level for finished composts, because this will normally decrease during composting of wastes, organic matter on dry weight basis of typical finished composts is in the range of $30-70 \%$.

Thus, the results in

indicate that the organic matter content of the compost (46.25\%) and vermicompost (37.92\%) for the present study are consistent with this range.

Furthermore, the carbon to nitrogen ratio $(\mathrm{C}: \mathrm{N})$ for the compost used was 12.01 while that of the vermicompost was 10.56 . These ratios could also serve as indicators of the stability of the compost and nitrate availability. Literature studies revealed that composts with high $\mathrm{C}$ : $\mathrm{N}$ ratios $(>30)$ will likely immobilize nitrate upon application, whereas composts with low $\mathrm{C}$ : $\mathrm{N}$ ratios $(<20)$ will mineralize organic nitrogen to inorganic, plant-available forms of nitrate.

The $\mathrm{C}$ : $\mathrm{N}$ ratios from the analysis mean both composts have the potential to mineralize $\mathrm{N}$ to meet crop nutrient demand when applied to soil. In addition, if the quantity of $\mathrm{N}$ contained in the organic residue is higher than that needed by the microbial biomass, net mineralisation of $\mathrm{N}$ will occur with the release of inorganic nitrogen $\mathrm{N}$, but if the amount is the same as the amount needed by the microbial biomass, the net mineralisation will not take place [8].

The foregoing discussion indicates that the quantity of carbon to nitrogen in organic residues such as those of compost and vermicompost used in this study are significant factors influencing the net mineralisation of $\mathrm{N}$ or its net immobilization. Furthermore, organic substances with a carbon to nitrogen ratio of below $20(<20)$ usually releases mineral nutrient $(\mathrm{N})$ early during decomposition in comparison to those with higher ratios between 20 and $30(>20)$. Organic compost with carbon to nitrogen ratio above 30 will result in immobilization at the initial decomposition process. Whitmore [9] noted that the carbon to nitrogen ratio of organic residues is related to the quantity of mineralized $\mathrm{N}$ and that the break-even point between net mineralisation of $\mathrm{N}$ and its net immobilization can be found between carbon to nitrogen ratios of 20 and 40, which is in line with the results obtained in this study.

Similarly, the moisture content from the analysis; $53.07 \%$ for the compost, $77.99 \%$ for vermicompost, revealed that both had high moisture content typical of finished composts. Literature review indicated that typical finished compost should have a percentage solids content of 50-60\% (50-40\% moisture). The high moisture content plays significant role in the mineralisation of organic nitrogen into available inorganic form of nitrate. This is because moisture content coupled with soil temperature influences the rapid decomposition and release of nutrients from composts in the soil. A study by Quemada and Cabrera [10] discovered a strong interplay between temperature and water content in the $\mathrm{N}$ mineralisation from surface-applied crimson clover (Trifolium incarnatum L.) residues. It was also discovered that the effects of temperature and water content on mineralisation from soil organic matter differ from the effects of temperature and water content on the mineralisation of $\mathrm{N}$ for surface-applied residues. 
Table 1. Typical Nutrient Compositions of the compost and vermicompost prior to incubation

\begin{tabular}{|l|c|c|}
\hline Property & Compost & Vermicompost \\
\hline Organic matter $(\%)$ & 46.25 & 37.92 \\
\hline NO3 $(\mathrm{mg} / \mathrm{kg})$ & 257.3 & 1407.3 \\
\hline NH4 $(\mathrm{mg} / \mathrm{kg})$ & 0.00 & 82.83 \\
\hline Total $\mathrm{N}(\%)$ & 2.23 & 1.91 \\
\hline Available $\mathrm{K}(\mathrm{mg} / \mathrm{kg})$ & 3987 & 3680 \\
\hline Total $\mathrm{K}(\mathrm{mg} / \mathrm{kg})$ & 5126.67 & 4228.33 \\
\hline Available P $(\mathrm{mg} / \mathrm{kg})$ & 257.1 & 221.6 \\
\hline Total P $(\mathrm{mg} / \mathrm{kg})$ & 5355.02 & 5135.94 \\
\hline Total Carbon $(\%)$ & 26.79 & 20.17 \\
\hline C/N & 12.01 & 10.56 \\
\hline Total Organic Carbon $(\%)$ & 33.05 & 25.39 \\
\hline Ph & 7.16 & 5.02 \\
\hline Water content $(\%)$ & 53.07 & 77.99 \\
\hline
\end{tabular}

\section{Nutrient Release Characteristics from Compost and Vermicompost}

The results of the cumulative $\mathrm{NO}_{3}-\mathrm{N}$ and $\mathrm{NH}_{4}-\mathrm{N}$ release from the compost and vermicompost during the incubation experiment displayed in table 1 showed that the both compost fertilizers used had high content of nitrate $\left(\mathrm{NO}_{3}-\mathrm{N}\right)$ than ammonium $\left(\mathrm{NH}_{4}{ }^{+}-\mathrm{N}\right)$. The higher content of nitrate indicates these are stable, mature and finished composts. In stable, finished composts such as those used for this study, most of the nitrate would be in the organic form; this organic nitrate is only slowly mineralized and made available to plants unlike the $\mathrm{NH}_{4}-\mathrm{N}$ and $\mathrm{NO}_{3}-\mathrm{N}$ that are immediately made available to plants. Compost and vermicompost from organic materials differ in their nutrient characteristics depending on the nature and type of the material used in composting. According to Amlinger [11] N mineralisation rates of between 5-15\% in an incubation experiment as well as 3-5\% in a 21-year field experiment were obtained in the first year of compost application whereas Gutser et al., [12] and Passoni et al., [13] noted an $\mathrm{N}$ mineralization of between $0-20 \%$ and $35-40 \%$ respectively. These findings however, cannot be compared because the experiments were conducted on different soils, soil management, and with different types of composts. 
Table 2. Cumulative $\mathrm{NO}_{3}{ }^{-}-\mathrm{N}$ and $\mathrm{NH}_{4}{ }^{+}-\mathrm{N}$ release during the incubation experiment

\begin{tabular}{|c|c|c|c|c|c|c|}
\hline Treatments & $\mathrm{NO}_{3}{ }^{-} \mathrm{N}$ & $S E$ & $\mathrm{NH}_{4}^{+}-\mathrm{N}$ & $\overline{S E}$ & Total & $S E$ \\
\hline$S C 30$ & 110.7 & 16.05 & 50.5 & 10.6 & 161.2 & 26.65 \\
\hline$S C 70$ & 208 & 30.61 & 50.5 & 16.07 & 258.5 & 46.68 \\
\hline SC120 & 298.5 & 13.79 & 58.3 & 15.37 & 356.8 & 29.16 \\
\hline SV3O & 365.5 & 66.25 & 95.3 & 35.88 & 460.8 & 102.13 \\
\hline SV70 & 882.5 & 223.59 & 158.8 & 50.82 & 1041.3 & 274.41 \\
\hline SV120 & 1225.3 & 120.55 & 122.3 & 11.64 & 1347.7 & 132.19 \\
\hline
\end{tabular}

$(\mathrm{SE}=$ Standard Error $)$

\section{Nutrient release patterns at different rates of Compost and Vermicompost mixed with Soil}

Table 3 shows the mean values of the amount of nutrients released from each of compost and vermicompost mixed with soil at different rates, and the nutrient release patterns are represented in figures 1 and 2 respectively. The results showed that both compost fertilizers exhibited typical characteristic release patterns consistent with all organic-based manures, that is, the nutrient release follow a slow, gradual process as indicated by the graphical patterns.

Table 3. Mean concentration of mineralized $N$ across the days of incubation experiment

\begin{tabular}{|l|l|l|l|l|l|l|l|l|l|l|}
\hline & \multicolumn{2}{|c}{ Day 0 } & \multicolumn{2}{c}{ Day 1 } & \multicolumn{3}{c|}{ Day 7 } & \multicolumn{2}{c|}{ Day 14 } & \multicolumn{2}{|r|}{ Day 21 } \\
\hline SampleId & Mean & SE & Mean & SE & Mean & SE & Mean & SE & Mean & SE \\
\hline SC30 & 22 & 7 & 13 & 4 & 48 & 7 & 40 & 8 & 40 & 1 \\
\hline SC70 & 36 & 11 & 28 & 11 & 52 & 7 & 71 & 11 & 71 & 6 \\
\hline SC120 & 60 & 9 & 55 & 9 & 69 & 8 & 87 & 1 & 87 & 1 \\
\hline SV30 & 63 & 24 & 93 & 29 & 105 & 13 & 92 & 13 & 107 & 23 \\
\hline SV70 & 173 & 75 & 318 & 120 & 171 & 23 & 177 & 11 & 202 & 45 \\
\hline SV120 & 241 & 39 & 286 & 51 & 259 & 19 & 287 & 4 & 275 & 19 \\
\hline
\end{tabular}

$(\mathrm{SE}=$ Standard Error $)$

\section{Nutrient release pattern from Soil-Compost combinations (SC)}

The graph of the nutrient release patterns in soil-compost treatment is shown in Figure 1. The nitrate mineralisation varied with the application rates as revealed in Figure 1. Note that the error bars overlapped at only one point which suggests that all points except at point day 7 after incubation with respect to treatment SC30 and SC70 are significantly different. 
The initial concentration of nitrate was higher at point day 0 than the observed concentration at point day 1 as shown in Figure 1. This could be due to the fact that $\mathrm{N}$ mineralisation did not occur prior to this point because it was a gradual, slow process. There was a gradual slow release pattern after day 1 until day 14 when it plateaus throughout the remaining days (Figure 1). The nitrate mineralisation varied with the application rates. Among all the treatments, the treatment which received 120t/ha (SC120) released the highest net mineralisation of $\mathrm{N}(87.33 \mathrm{mg} / \mathrm{kg})$ at point day 21 , followed closely by treatment which received $70 \mathrm{t} / \mathrm{ha}$ (SC70) with net mineralisation of $71.33 \mathrm{mg} / \mathrm{kg}$ at point day 14 . The nutrient release for treatment with SC30, 30t/ha peaked at point day 7 where the amount of nutrient released was $47.83 \mathrm{mg} / \mathrm{kg}$, but remained constant and immobilized throughout the remaining days 14 and 21 $(39.50 \mathrm{mg} / \mathrm{kg})$. This result is in line with a study conducted by Adeoye [14] who examined the influence of different EFB composts on oil palm nursery in which the manure was applied at a rate of $4.8 \mathrm{~g} \mathrm{~N}$ per plant, it was observed that oil palm empty fruit bunch compost mixed with cow excrement raised the performance of oil palm seedlings.

Also prior study by Danso et al., [15] showed that mixing $7.5 \mathrm{~kg}$ EFB (7500g) compost together with topsoil could substitute the standard mineral fertilization in main nursery stage as the 12-month-old oil palm seedling grows as good as seedlings under normal fertilization methods.

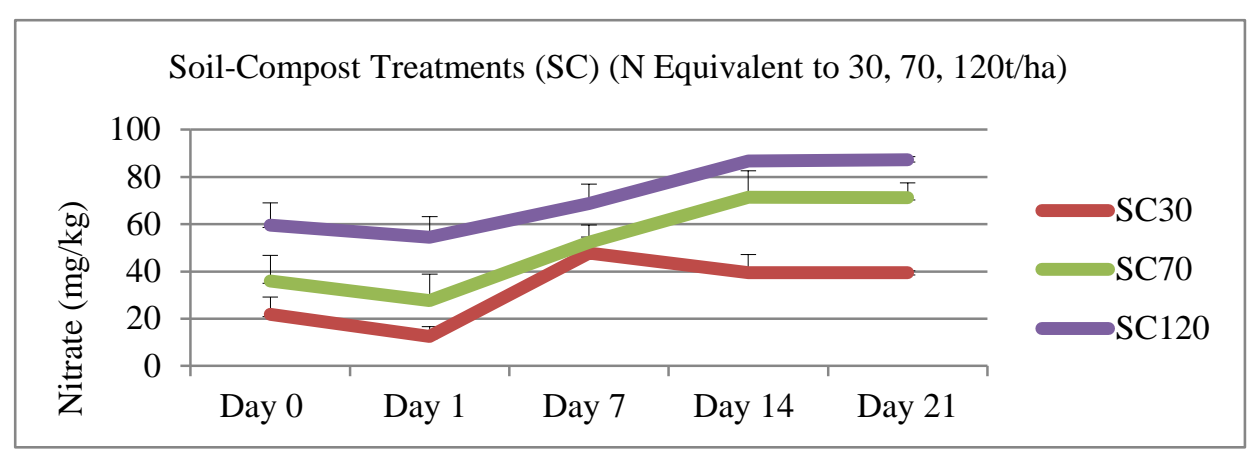

Figure 1. Nitrate-release patterns during the incubation experiment influenced by soil-compost application rates

\section{Nutrient release pattern from Soil-Vermicompost combinations (SV)}

The graph of the nutrient release pattern from soil-vermicompost combinations across the days of incubation is shown in Figure 2. The error bars are indicated to show significant differences in the characteristics release patterns between the various application rates.

There was an observed marked increase in the concentration of mineral nitrogen in $\mathrm{NH}_{4}{ }^{+}-\mathrm{N}$ and $\mathrm{NO}_{3}-\mathrm{N}$ in the soil-vermicompost application rate of $70 \mathrm{t} / \mathrm{ha}(\mathrm{SV70})$ that peaked at point day $1(318.33 \mathrm{mg} / \mathrm{kg})$. This could be due to the low carbon to nitrogen ratio of the vermicompost used (10.56). 
The result is in line with Tisdale et al. (1990) who observed that organic substances with a carbon to nitrogen ratio of below $20(<20)$ usually release mineral nutrient $(\mathrm{N})$ early during decomposition in comparison to those with higher ratios between 20 and 30 $(>20)$. Organic compost with carbon to nitrogen ratio above 30 will result in immobilization at the initial decomposition process.

The nitrate mineralisation in treatments with 120t/ha equivalent to (SV120) was observed to follow a gradual slow release pattern from day 0 after incubation until day 14 where the net peak $\mathrm{N}$ mineralisation $(286.50 \mathrm{mg} / \mathrm{kg})$ occurred as seen in Figure 2 . On the other hand, the observed concentration of nutrient released between treatments which received 70t/ha (SV70) and 120t/ha (SV120) at points day 0 and day 1 where the error bars overlapped at the two points for both treatments was not statistically significant. Evidence from literature revealed that the amount of mineral nitrogen released into the soil increased with increase in the rate of application of manures and chemical fertilisers. The gradual slow mineralisation of nitrogen could be due to the low $\mathrm{C}$ : $\mathrm{N}$ ratio (10.56) of the vermicompost, which is less than 20 .

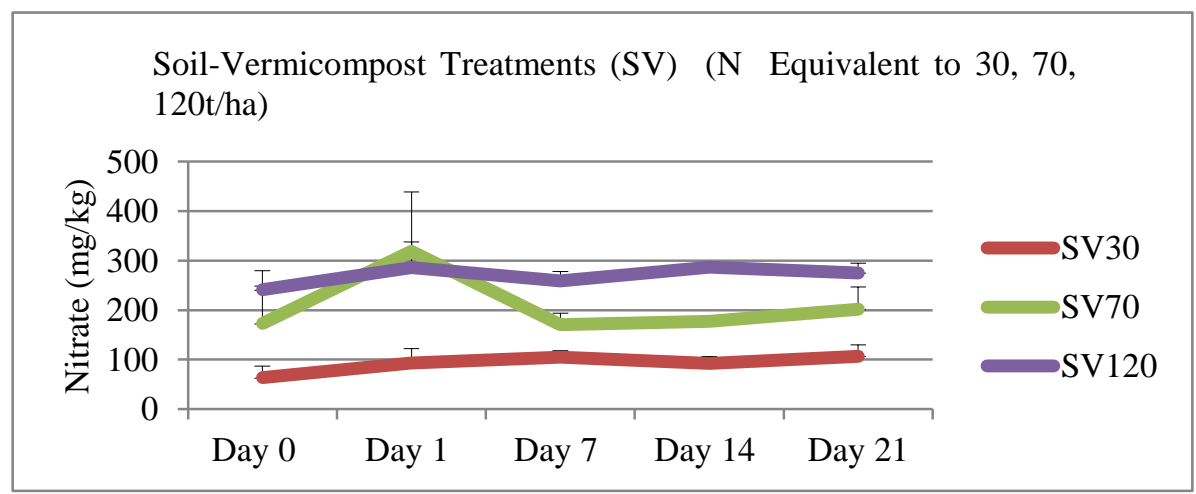

Figure 2. Nitrate-release patterns during the incubation experiment influenced by soil-vermicompost application rates

\section{CONCLUSIONS}

Soil amendment materials derived from oil palm waste compost and vermicompost in soil growing media have been variously reported in literature to have long-term beneficial effects on the growth and development of the crop by Rupani et al., [16] and Tisdale et al., [17]. The incubation experiment conducted in the laboratory indicated that all treatment combinations (SC and SV) had significant influence on the slow, gradual release of nutrient across the days of incubation. Thus, the use of slow release compost and vermicompost fertilizers could benefit the soil of agriculture both from environmental aspects by maintaining soil structural and textural properties as well as overall health status of the soil, and economic aspect in terms of improved crop yields to farmers in the long run. 


\section{REFERENCES}

[1] Sanjukta Biswas (2014). 'Evaluation of growth, yield and nutrient content with microbial Inconsortia combined with different organic manures in Rumex Inacetosella L. In', IOSR Journal of Environmental Science, Toxicology and Food Technology (IOSR-JESTFT), 8(11), pp. 01-05. Available at: http://www.iosrjournals.org/iosr-jestft/papers/vol8issue11/Version-2/A081120105.pdf.

[2] Tolanur, S. I. (2009). 'Effect of Compost , Vermicompost Farm Yard Manure , Green Manuring and Fertilizer Nitrogen on Yield and Uptake of Major Nutrients By Rabi-Sorghum in Vertisol', 29(1), pp. 60-62.

[3] Sinha, J., Biswas, C. K., Ghosh, A. and Saha, A. (2010) 'Efficacy of Vermicompost against fertilizers on Cicer and Pisum and on population diversity of $\mathrm{N} 2$ fixing bacteria', Journal of Environmental Biology, 31(3), pp. 287-292.

[4] Nourbakhsh, F. (2007). 'Influence of vermicomposting on solid wastes decomposition kinetics in soils.', Journal of Zhejiang University. Science. B, 8(10), pp. 725-730. doi: 10.1631/jzus.2007.B0725.

[5] Parr, J. P., Harrick, S. B. and Papendick, R. I. (1998). 'Transition from conventional agriculture to natural farming systems. The role of microbial inoculants and biofertilizer', Fourth International Conference on Kyusei Nature Farming, p. 56-63.

[6] Chen K.-S., Lin Y.-S., Yang S.-S. (2007). 'Application of thermo tolerant microorganisms for biofertiliser preparation.' Journal of microbiology, immunology, and infection. Wei mian yu gan ran za zhi, 40(6), pp. 462-473.

[7] Parr, J. P., Harrick, S. B. and Papendick, R. I. (1998). 'Transition from conventional agriculture to natural farming systems. The role of microbial inoculants and biofertilizer', Fourth International Conference on Kyusei Nature Farming, p. 56-63.

[8] Cabrera M. L., Kissel D. E. and Vigil M. F. (2005). 'Nitrogen mineralization from organic residues: research opportunities. Journal of Environmental Quality, 34, pp. 75-9. doi: doi:10.2134/jeq2005.0075.

[9] Whitmore, A. P. (1996). 'Modelling the release and loss of nitrogen after vegetable crops', Netherlands Journal of Agricultural Science, pp. 73-86.

[10] Quemada, M. and Cabrera, M. L. (1997) 'Temperature and moisture effects on C and N mineralization from surface applied clover residue', Plant and Soil, pp. 127-137. doi: 10.1023/A:1004281804058.

[11] Amlinger F., Gotz B., Dreher P., Geszti J., Weissteiner C. (2003). Nitrogen in biowaste and yard waste compost: Dynamics of mobilization and availability - A review, European Journal of Soil Biology, vol. 39, no. 3, pp. 107-116.

[12] Gutser R., Ebertseder T., Weber A., Schraml M., Schmidhalter U. (2005). Short-term and residual availability of nitrogen after long-term application of organic fertilisers on arable land, Journal of Plant Nutrition and Soil Science, vol. 168, no. 4, pp. 439-446.

[13] Passoni M., Bonn M. (2009). Effects of different composts on soil nitrogen balance and dynamics in a biennial crop succession. Compost Science and Utilisation, vol.17, No.2, pp. 108-116.

[14] Adeoye, G. O. (2008). 'Potential of Oil Palm Empty Fruit Bunch (EFB) as Fertilizer in Oil Palm ( Elaeis guinensis L Jacq .) Nurseries', pp. 20-22.

[15] Danso, F., Adu, C., Opoku, A., Danso, I., Anim Okyere, S. and E, L. (2013). 'Raising oil palm seedlings using sole and amended green-gro compost', International Research Journal of Agricultural Science and Soil Science 3(10), pp. 362-368. Available at: https://globalscienceresearchjournals.org/gjarr/639712013833.

[16] Rupani, P. and Singh, R. (2010). 'Review of current palm oil mill effluent (POME) treatment methods: Vermicomposting as a sustainable practice', World Applied Sciences ..., 11(1), pp. 70-81. doi: 10.5539/jas.v7n4p68. 
[17] Tisdale, L.S., Nelson, L.W and Beaton, J.D. (1990). Soil fertility and fertilizers. 4th ed, Macmillan Publishing Company, New York.

\title{
NUTRITIVNE VREDNOSTI KOMPOSTA, VERMIKOMPOSTA I DUGOROČNI EFEKAT NA STATUS PLODNOSTI ZEMLJIŠTA
}

\author{
Amos D. Umaru ${ }^{1}$, Precious O. Ehiomogue ${ }^{* 2}$, Stephen O. Ojedele Francis N. Orji ${ }^{2}$, \\ Ikechukwu Okosa', Chidinma E. Ikechukwu-Edeh ${ }^{2}$ \\ ${ }^{I}$ Federal University of Agriculture, Department of Agribusiness, P.M.B. 2373, Makurdi, \\ Nigeria. \\ ${ }^{2}$ Michael Okpara University of Agriculture, Umudike Department of Agricultural and \\ Bio-resources Engineering, P.M.B. 7267 Umudike, Nigeria
}

Sažetak: Glavni cilj ove studije je bio ispitivanje obrazca oslobađanja hranljivih materija iz dva tipa komposta i dugoročne posledice na status plodnosti zemljišta. Izvršen je eksperiment inkubacije u laboratoriji da bi se utvrdili obrasci oslobađanja hranljivih materija iz komposta i vermikomposta pomešanih sa zemljištem, pri različitim količinama kombinacijama primene SC30, SC70, SC120 i SV30, SV70 SV120, tokom 21 dan. Početne pre inkubacijske analize kompostnog materijala korišćenog za eksperiment pokazale su da i kompost i vermikompost imaju visok sadržaj hranljivih sastojaka. Rezultati istraživanja pokazuju da su različite količine unetog komposta i vermikomposta u zemljište imale značajan uticaj na spor, postepen proces oslobađanja, hranljivih materija, što ukazuje na dugoročni efekat koji organsko đubrivo može da ima na status plodnosti zemljišta.

Ključne reči: Kompost; Vermicompost; Ispuštanje hranljivih sastojaka; Plodnost zemljišta.

Prijavljen:

Submitted:

Ispravljen:

Revised:

Prihvaćen:

Accepted:

\footnotetext{
*Corresponding Author. Email: ehiomogue.precious@mouau.edu.ng
} 